NBER WORKING PAPER SERIES

\title{
SELF-EMPLOYMENT IN OECD COUNTRIES
}

\author{
David G. Blanchflower \\ Working Paper 7486 \\ http://www.nber.org/papers/w7486 \\ NATIONAL BUREAU OF ECONOMIC RESEARCH \\ 1050 Massachusetts Avenue \\ Cambridge, MA 02138 \\ January 2000
}

Presented at Canadian International Labor Network (CILN) Conference, Burlington Ontario, September 24 ${ }^{\text {th }}$ 26 $6^{\text {th }}$ 1998. I am grateful to CILN for financial support and David Bell, Dwayne Benjamin, Peter Kuhn, Herb Schuetze, Andrew Oswald and an anonymous referee for helpful comments and suggestions. All errors are my responsibility. The views expressed herein are those of the author and not necessarily those of the National Bureau of Economic Research.

(C) 2000 by David G. Blanchflower. All rights reserved. Short sections of text, not to exceed two paragraphs, may be quoted without explicit permission provided that full credit, including $\mathbb{C}$ notice, is given to the source. 


\title{
Self-Employment in OECD Countries
}

David G. Blanchflower

NBER Working Paper No. 7486

January 2000

JEL No. J2

\begin{abstract}
This paper describes measurement of a self-employment rate and the important role the agricultural sector plays in any analysis of the determinants of self-employment. The determinants of the self-employment rate are modeled using a panel of 23 countries for the period 1966-1996. A similar analysis is then performed at the level of the individual using a time-series of cross-sections for the period 1975-1996 for 19 countries. For most countries there is a negative relationship between the self-employment rate and the unemployment rate. It is also shown that the self-employed are more satisfied with their jobs than are individuals who are not their own boss. I developed a flexibility index based on information provided by individuals in 1995. According to this index, the U.S. economy was the most flexible, followed by Canada, Germany and the Netherlands. Latvia, Russia and Hungary were found to be the least flexible countries. Of the OECD countries examined, Austria and Ireland were ranked lowest.
\end{abstract}

David Blanchflower

Department of Economics

6106 Rockefeller Hall

Dartmouth College

Hanover, NH 03755-3514

david.g.blanchflower@dartmouth.edu 
A large proportion of the labor force apparently would like to be their own bosses. Selfemployment presents an opportunity for the individual to set his or her own schedule, to work when they like, to answer to nobody and possibly even as a way to become rich. Unfortunately on the downside, if the business fails the individual may lose their job, their savings, their home if as often happens it is used as security on a loan, and perhaps even their marriage because of the stresses and strains. If we have learnt anything from portfolio theory it is that an individual should diversify their portfolio and not to pool their resources into a single risky activity.

Governments on the other hand frequently see self-employment as a route out of poverty and disadvantage and for this reason offer aid and assistance for small businesses. The justification for these actions are usually that it is argued that self-employment will help promote invention and innovation and thus create new jobs; new firms may also raise the degree of competition in the product market bringing gains to consumers; greater self-employment may also go along with increased self-reliance and well being. Unfortunately economists have little evidence on whether these hypothetical benefits exist in practice. Even the widely held view, best expressed in Birch (1979), that small firms disproportionately are the creators of jobs has been challenged by Davis, Haltiwanger and Schuh (1996) who have undertaken the most careful empirical analysis of the job creation process to date ${ }^{1}$. They argue persuasively that "conventional wisdom about the job creating powers of small businesses rests on statistical fallacies and misleading interpretations of the data" (1996, p.57). Indeed, they go on to conclude the following.

\footnotetext{
1 Studies of Canadian employers by Picot, Baldwin and Dupuy (1994), of Dutch manufacturing by Huigen, Kleijweg and van Leeuwen (1991), of Australian manufacturing establishments by Borland and Home (1994) and of German manufacturing firms by Wagner (1995) also find that standard measurement procedures exaggerate the relative growth performance of small firms.
} 
"It is true that small businesses create jobs in disproportionate numbers. That is gross job creation rates are substantially higher for smaller plants and firms. But because gross job destruction rates are also substantially higher for smaller plants and firms, they destroy jobs in disproportionate numbers. We found no strong systematic relationship between employer size and net job growth rates....Finally, and in contrast to the lack of a clear-cut relationship between employer size and job growth,...(we found)..clear evidence that large employers offer greater job durability" (1996, p.170).

Despite the lack of clear and convincing evidence (I learnt that phrase from the Starr report!) of the benefits of having a larger small business sector and/or having a higher proportion of the workforce self-employed, as noted above, many governments around the world provide subsidies to individuals set-up and to remain in business. In Britain and France, for example, government programs provide transfer payments to the unemployed while they attempt to start businesses. ${ }^{2}$ In the U.S. similar programs are being started for unemployment insurance and welfare recipients. Many countries, including the UK and the United States, have government programs to provide loans to small businesses, and even exempt small businesses from certain regulations and taxes. Furthermore, many states and municipalities in the U.S. have had programs to encourage minority and female-owned small businesses $^{3}$.

Probably the greatest interest in entrepreneurship springs from a belief that small businesses are essential to the growth of a capitalist economy. While the view that small businesses are responsible for a disproportionate share of job creation and innovation is disputed ${ }^{4}$, this view is a common one. It is

2 See Bendick and Egan (1987).

3 For a discussion of the existence of discrimination in the market for business loans see Blanchflower, Levine and Zimmerman (1998). The existence of these programs that offer preferential treatment to minorities and women is the subject of a series of challenges in the US courts. This paper is also being presented at this conference.

4 See Brown et. al. (1990) for a critical appraisal of these schemes. 
often argued that many of the problems of Eastern Europe come from the lack of entrepreneurs. Academics have been interested in self-employment as a safety valve where the unemployed and victims of discrimination could find jobs 5 . Interest in self-employment has also been prompted by the belief that they face a different set of economic incentives, and thus could be used to test various theories 6 .

The simplest kind of entrepreneurship is self-employment. There is recent survey evidence to suggest that, in the industrialized countries, many individuals who are currently employees would prefer to be self-employed. Although it cannot be definitive, this evidence suggests that there may be restrictions on the supply of entrepreneurs. The International Social Survey Programme ${ }^{7}$ of 1989 asked random samples of individuals from eleven countries the question:

"Suppose you were working and could choose between different kinds of jobs. Which of the following would you choose? I would choose...

(i) Being an employee

(ii) Being self-employed

(iii)Can't choose."

As can be seen from Table 1, large numbers of people gave answer (ii) and thus stated that they would wish to be self-employed. This answer was given by, for example, a remarkable $63 \%$ of Americans (out of 1453 asked), $48 \%$ of Britons (out of 1297), and $49 \%$ of Germans (out of 1575). Answers are similar when the sample is restricted to employees only. These numbers can be compared with an actual proportion of workers that are self-employed in these countries of approximately $15 \%$. As pointed out by a referee, one possible interpretation of the answers to this question is that individuals

\footnotetext{
5 See Light (1972), Moore (1983) or Sowell (1981).

6 See Wolpin (1977), Moore (1983) and Lazear and Moore (1984).

7 For information on the International Social Survey Programme data series see the Data Appendix.
} 
would like to be considered as self-employed by the tax authorities, thereby paying less tax. Numerous expenses such as travel-to-work costs are tax deductible for the self-employed but not for employees.

The data raise a puzzle: why do not more of these individuals follow their apparent desire to run a business? This paper explores the factors that may be important in determining who becomes and remains an entrepreneur across many countries. A number of other issues are examined including a) to what extent do the characterisitics of the self-employed vary across countries; b) the relationship between the self-employment rate, variously defined, and the unemployment rate across countries; c) how satisfied the self-employed are with their jobs; d) whether higher levels of self-employment increase the real growth rate of the economy; e) how mobile the self-employed are across neighborhoods, regions and towns. Finally I develop a flexibility index across countries based upon individuals' reports on how willing they are to move. According to this index the US economy was the most flexible, followed by Canada, Germany and the Netherlands. Latvia, Russia and Hungary are found to be the least flexible countries.

The paper uses data for a number of countries drawn from a variety of sources. The main source of data is the Eurobarometer Surveys conducted by EUROSTAT which provides information on member countries of the European union. These data are supplemented with cross-country data from the International Social Survey Programme series as well as the General Social Surveys for the United States and the Surveys of Consumer Finances in Canada. In the first section of the paper we discuss previous research findings. Section 2 describes measurement of a self-employment rate and the important role the agricultural sector plays in any analysis of the determinants of self-employment. It initially models the determinants of the self-employment rate using a panel of 23 countries for the period 1966-1996 and then performs a similar analysis of the determinants of self-employment at the level of 
the individual using a time-series of cross-sections for the period 1975-1996 for 19 countries. Section 3 examines whether the self-employed are more satisfied with their job than are individuals who are not their own boss. Section 4 examines whether self-employment enhances labor marker flexibility, Section 5 contains our conclusions.

\section{Previous research}

After years of comparative neglect, research on the economics of entrepreneurship-especially upon self-employment-is beginning to expand. Microeconometric work includes Fuchs (1982) Borjas and Bronars (1989), Evans and Jovanovic (1989), Evans and Leighton (1989), Fairlie (1999), Fairlie and Meyer (1996, 1998), Reardon (1998) for the United States, Rees and Shah (1986), Pickles and O'Farrell (1987), Blanchflower and Oswald (1990, 1998a); Blanchflower and Freeman (1994), Meager (1992), Taylor (1996), and Robson (1998a, 1998b) for the UK; DeWit and van Winden (1990) for the Netherlands; Alba-Ramirez (1994) for Spain; Bernhardt (1994), Schuetz (1998), Arai (1997), Lentz and Laband (1990) and Kuhn and Schuetz (1998) for Canada; Laferrere and McEntee (1995) for France; Blanchflower and Meyer (1994) and Kidd (1993) for Australia and Foti and Vivarelli (1994) for Italy. There are also several theoretical papers including Kihlstrom and Laffonte (1979), Kanbur (1982), Croate and Tennyson (1992), and Holmes and Schmitz (1990) plus a few papers that draw comparisons across countries i.e. Schuetze (1998) - Canada and the USA, Blanchflower and Meyer (1994) - Australia and the USA; Alba-Ramirez (1994) for Spain and the United States and Acs and Evans (1994) for many countries.

One possible impediment to entrepreneurship is lack of capital. In recent work using US micro data, Evans and Leighton (1989) and Evans and Jovanovic (1989) have argued formally that entrepreneurs face liquidity constraints. The authors use the National Longitudinal Survey of Young 
Men for 1966-1981 and the Current Population Surveys for 1968-1987. The key test shows that, all else remaining equal, people with greater family assets are more likely to switch to self-employment from employment. This asset variable enters probit equations significantly and with a quadratic form. Although Evans and his collaborators draw the conclusion that capital and liquidity constraints bind, this claim is open to the objection that other interpretations of their correlation are feasible. One possibility, for example, is that inherently acquisitive individuals both start their own businesses and forego leisure to build up family assets. In this case, there would be a correlation between family assets and movement into self-employment even if capital constraints did not exist. A second possibility is that the correlation between family assets and the movement to self-employment arises because children tend to inherit family firms.

Blanchflower and Oswald (1998a) find that the probability of self-employment depends positively upon whether the individual ever received an inheritance or gift. This emerges from British data, the National Child Development Study; a birth cohort of children born in March 1958 who have been followed for the whole of their lives. Second, when directly questioned in interview surveys, potential entrepreneurs say that raising capital is their principal problem. Third, the self-employed report higher levels of job and life satisfaction than employees. Fourth, psychological test scores play only a small role. Work by Holtz-Eakin, Joulfaian and Rosen (1994a, 1994b) drew similar conclusions using different methods on US data. The work of Black et al (1996) for the UK discovers an apparently powerful role for house prices (through its impact on equity withdrawal) in affecting the supply of small new firms. Cowling and Mitchell (1997) find a similar result. Again this is suggestive of capital constraints. Finally, Lindh and Ohlsson (1994) adopts the Blanchflower-Oswald procedure and provide complementary evidence for Sweden. Bernhardt (1994) in a study for Canada using data from 
the 1981 Social Change in Canada Project also found evidence that capital constraints appear to bind. Using the 1991 French Household Survey of Financial Assets, Laferrere and McEntee (1995) examined the determinants of self-employment using data on intergenerational transfers of wealth, education, informal human capital and a range of demographic variables. They also find evidence of the importance played by the family in the decision to enter self-employment. Intergenerational transfers of wealth, familial transfers of human capital and the structure of the family were found to be determining factors in the decision to move from wage work into entrepreneurship.

There has been relatively little work on how institutional factors influence self-employment. Such work that has been conducted includes examining the role of minimum wage legislation (Blau, 1987), immigration policy (Borjas and Bronars, 1989) and retirement policies (Quinn, 1980). Studies by Long (1982) and Blau (1987) and more recently by Schuetze (1998) have considered the role of taxes. In an interesting study pooling individual level data for the US and Canada from the Current Population Study and the Survey of Consumer Finances respectively Schuetze (1998) finds that increase in income taxes have large and positive effects on the male self-employment rate. He found that a 30 percent increase in taxes generated a rise of 0.9 to 2 percentage points rise in the male selfemployment rate in Canada compared with a rise of 0.8 to 1.4 percentage point rise in the US over 1994 levels.

A number of other studies have also considered the cyclical aspects of self-employment and in particular how movements of self-employment are correlated with movements in unemployment. Meager (1992) provides a useful summary of much of this work. Evans and Leighton found that white men who are unemployed are nearly twice as likely as wage workers to enter self-employment. Bogenhold and Staber (1991) also find evidence that unemployment and self-employment are positively 
correlated. In Blanchflower and Oswald (1990) we found a strong negative relationship between regional unemployment and self-employment for the period 1983-1989 in the UK using a pooled crosssection time-series data set ${ }^{8}$. In Blanchflower and Oswald (1998a) we confirmed this result, finding that the log of the county unemployment rate entered negatively in a cross-section self-employment probits for young people age 23 in 1981 and for the same people aged 33 in 1991. Taylor (1996) confirmed this result using data from the British Household Panel Study of 1991, showing that the probability of being self-employed rises when expected self-employment earnings increase relative to employee earnings, i.e. when unemployment is low. Acs and Evans (1994) found evidence from an analysis of a panel of countries that the unemployment rate entered negatively in a fixed effect and random effects formulation. However, Schuetze (1998) found that, for the US and Canada that the elasticity of the male self-employment rate with respect to the unemployment rate was considerably smaller than he found for the effect from taxes discussed above. The elasticity of self-employment associated with the unemployment rate is about 0.1 in both countries using 1994 figures. A decrease of 5 percentage points in the unemployment rate in the US (about the same decline occurred from 1983-1989) leads to about a 1 percentage point decrease in self-employment. It does seem then that there is some disagreement in the literature on whether high unemployment acts to discourage self-employment because of the lack of available opportunities or encourage it because of the lack of viable alternatives.

There is, however, a good deal of agreement in the literature on the micro-economic correlates

8 Self-employment as a percentage of civilian employment and the OECD standardised unemployment rate in the UK over the years 1983-1989 were as follows (Source: OECD Economic Outlook).

$\begin{array}{lrrrrrrrr} & 1983 & 1984 & 1985 & 1986 & 1987 & 1988 & 1989 & \\ \text { Unemployment rate (\%) } & & 12.4 & 11.7 & 11.2 & 11.2 & 10.3 & 8.6 & 7.2 \\ \text { Self-employment rate (\%) } & & 9.6 & 11.4 & 11.5 & 11.5 & 12.4 & 12.6 & 13.3\end{array}$


of self-employment (see Aronson, 1991) on this. It should be pointed out that most of this work is based on US data and, as we shall see below, the results do not necessarily carry through elsewhere. Subject to that caveat it appears that self-employment rises with age, is higher amongst men than women and higher among whites than blacks. Increases in educational attainment are generally found to lead to increases in the probability of being self-employed. The more children in the family the higher likelihood of (male) self-employment. Workers in agriculture and construction are also especially likely to be self-employed.

\section{The determinants of self-employment}

The self-employed are a very disparate group. They are likely to include farmers, craftsmen, shopkeepers, lawyers, doctors, architects, entertainers, sportsmen and women, computer programmers and analysts amongst others. Unfortunately most of the data files we have access to do not report the occupation of the self-employed person - self-employment is the reported occupation. It would be a good idea, as suggested by a referee, to analyze self-employment for a distinct occupational group such as cleaning and catering, but unfortunately this is not possible with the data we have available to us.

It turns out it is also not a simple matter to determine whether an individual is actually selfemployed or not. It is certainly not a simple task to do so in a consistent way across countries. Some of the individuals who report being self-employed are unpaid family workers. This is considerably more prevalent in the agricultural sector than it is in non-agriculture - the unweighted average over the sixteen countries for which I have data in 1996 is $19.6 \%$ in agriculture and $7.3 \%$ in the non-agricultural sector and $11.6 \%$ overall. There is also considerable variation by country - overall $33.6 \%$ of the selfemployed in Japan are unpaid family workers compared with $1.7 \%$ in the USA; $12.9 \%$ in Germany; 
$14.0 \%$ in Italy and $3.7 \%$ in Canada ${ }^{9}$. The extent to which individuals report being unpaid family workers is likely to be a function of both the tax regime and the welfare system prevailing within a country. It does not seem to be appropriate to simply throw away these individuals from any analysis; not least because there are other ways of remunerating the self-employed than via a wage. An example would be that an individual's expenses can be charged to the business and/or the value of the business may increase over time even though no salary is being paid. In my experience this is more of a problem in Europe than it is in North America. Earnings data for the self-employed seem to convey some information in the US. In the UK, for example, earnings of the self-employed are low and frequently zero or negative.

There is a further issue which needs to be confronted - how to deal with the owners of larger businesses - know in the USA as the incorporated self-employed. In the USA they are usually treated as employees (see Bregger, 1996). In Europe, and as far as I am aware in most of the rest of the OECD, they are included in the self-employment count. In a paper like this it is difficult to reconcile these differences. The approach we take in this paper to overcome these definitional problems is as follows.

1. Analyze a series of micro-data files that have been collected across several countries with similar sample design, definitions and questions.

2. Pool data across countries and through time and include a group of country and year fixed effects in an attempt to control for the nuances of the economic and legislative environment within which the self-employed operate.

9 The proportion of the self-employed that are unpaid family workers in the remaining countries in 1996 was Australia 6.1\%; Denmark 10.6\%; Finland 4.6\%; Iceland 2.3\%; Ireland 5.1\%; Netherlands 9.6\%; Norway 10.3\%; 
3. Work with the official data published by the OECD who have made considerable efforts over the years to make these estimates as comparable as possible across countries (see Annex 4A, OECD, 1992).

There is also considerable disagreement on how the self-employment rate should be measured. As we show below differences in results across papers are on occasions to be explained by differences in what is included in the denominator of the self-employment rate as well as on the sample restriction rules used. The problem is twofold. First, there is a good deal of disagreement in the literature whether the self-employed to be examined should include individuals working in both agriculture and nonagriculture. Second, there are three main ways of measuring the denominator

a) employees,

b) the labor force (employees plus unemployed),

c) the population and sometimes restricted to include the population ages 16 - 65 .

In this section we consider what if any differences arise in modeling self-employment as a result of such differences in definition and sample selection.. Table 2 reports data on the change in the proportion of all workers who were self-employed for the years 1966, 1976, 1986 and 1996 in our sample of 23 countries (Australia, Austria, Belgium, Canada, Denmark, Finland, France, Germany, Greece, Iceland, Ireland, Italy, Japan, Luxembourg, Netherlands, New Zealand, Norway, Portugal, Spain, Sweden, Turkey, UK, USA). Data are taken from various issues of the OECD Economic Outlook. In 1996 the highest proportions were found in Turkey (58\%) and Greece (46\%) and the lowest in Luxembourg (7.5\%) and the USA. (8.4\%). If we compare the two end years we observe that over the last 30 years this rate fell in all countries except Iceland, New Zealand, Portugal and the UK.

Portugal 5.8\%; Spain $14.3 \%$; Sweden $3.4 \%$. 
Table 3, which presents the proportion of non-agricultural work that is accounted for by the self-employed also shows considerable diversity in experience across countries. However, now there are several additional countries where there has been an upward trend between 1966 and 1996 (Australia, Canada, Finland, Iceland, Ireland, Portugal, Sweden, New Zealand and the United Kingdom) than was found in Table 2, which included both the agriculture and non-agricultural sectors. Clearly there are broad similarities with the trends in self-employment identified in the two tables. Overall, the predominant trend in self-employment is downward; the main exceptions are New Zealand, Portugal and the UK where there have been substantial increases in the self-employment rate, however measured.

The next issue we examine is what are the determinants of self-employment and to what extent do they vary across countries? We do so in Table 4 by estimating five self-employment equations using different definitions of the dependent variable. Total observations are 626 for the years 1966-1996; using a lagged dependent variable reduces the sample size to 600 . The data set is an unbalanced panel. As we move across the columns the definition of self-employment is varied ${ }^{10}$. Included in each of the regressions is a lagged dependent variable, a time trend (1966=zero), the percentage of total employment in agriculture, 21 country dummies, the natural logarithm of the unemployment rate and a full set of interactions between the country dummies and the log of the unemployment rate. The main conclusions are as follows

\footnotetext{
10 Definitions of the dependent variables in Table 7 are as follows -- column $1=$ self employment/total employment; column $2=$ self employment/labor force; column $3=$ self employment/ population aged $16-64$; column $4=($ selfemployed/all workers) -in the non-agricultural sector; column $5=$ (self-employed/all workers) in the agricultural sector.
} 
1) In the first four equations the trend in self-employment is positive and significant. It is negative in the final column for the agricultural sector.

2) As might be expected, the higher the percentage of workers in agriculture, the higher the various self-employment rates. The variable is insignificant in the agricultural sample in the last column of the table.

3) The unemployment rate enters significantly with a negative coefficient when entered on its own without any interaction terms when the dependent variable is defined only as in column 3 (results not reported) but is insignificant in the other specifications of the dependent variable used in Table 4 (results also not reported). The significance of the various interaction terms suggests there is considerable variation across countries in the influence of unemployment, both in terms of the direction and magnitude of any effect. If we look at the first column where self-employment is expressed as a proportion of total employment, the unemployment rate enters negatively in Austria, which is the excluded category ${ }^{11}$. There is an even larger negative effect in Japan. Most of the other coefficients are positive, although in a number of cases the t-statistic is low suggesting that the effect of the unemployment rate is not significantly different from that of Austria (i.e. Denmark, Luxembourg, Portugal, Canada, France, Netherlands, Germany, USA). Even though most of the other interaction terms have significant t-statistics, implying that the effect of unemployment in that country is significantly higher than it is in Austria, only in Iceland and Italy $(\mathrm{t}=2.3$ and 6.0 respectively) does the unemployment effect turn positive. There is evidence of even stronger negative unemployment effects when the sample is restricted to agriculture in the final column. Some

\footnotetext{
11 The t-statistics reported on the unemployment and country interaction terms test whether the coefficient is
} significantly different from the excluded category Austria whose coefficient is that on the unemployment rate (-.0190). 
experiments were done with lags on the unemployment rate in all five columns and the results were similar.

Any labor economist worth his salt is not going to limit him or herself to time-series data, so in the time honored fashion I move on to modeling self-employment using micro data. I make use of a data file I have constructed at the level of the individual for 19 countries $^{12}$ and just under 575,000 people. Data are taken from various Eurobarometer Surveys conducted by the European Commission for the years 1975-1996 which was merged with a set of data drawn from the United States from the General Social Surveys. The Eurobarometer Surveys cover member countries in all years as well as potential members even before they join - hence information is available on Norway for a few years even though the Norwegians actually voted not to join the EU. A considerable amount of preliminary data work had to be conducted to put these 45 separate surveys on a comparable basis. The numbers of observations by country and the years for which data are available are as follows

$\begin{array}{lcc}\text { Country } & N & \text { Years } \\ \text { Austria } & 3887 & 1995-96 \\ \text { Belgium } & 45863 & 1975-96 \\ \text { Denmark } & 48481 & 1975-96 \\ \text { East Germany } & 16347 & 1990-96 \\ \text { Finland } & 4392 & 1995-96 \\ \text { France } & 46599 & 1975-96 \\ \text { Great Britain } & 44338 & 1975-96 \\ \text { Greece } & 35988 & 1981-96 \\ \text { Ireland } & 45010 & 1975-96 \\ \text { Italy } & 50942 & 1975-96 \\ \text { Luxembourg } & 21029 & 1975-96 \\ \text { Netherlands } & 48556 & 1975-96 \\ \text { Northern Ireland } & 13734 & 1975-96\end{array}$

12 The countries are Austria, Belgium, Denmark, East Germany, Finland, France, Great Britain, Greece, Ireland, Italy, Luxembourg, Netherlands, Northern Ireland, Norway, Portugal, Spain, Sweden, West Germany and the United States. 


$\begin{array}{lrr}\text { Norway } & 7960 & 1991-95 \\ \text { Portugal } & 30958 & 1985-96 \\ \text { Spain } & 27340 & 1985-96 \\ \text { Sweden } & 4084 & 1995-96 \\ \text { USA } & 30117 & 1975-96 \\ \text { West Germany } & 46131 & 1975-96 \\ \text { Total } & 571756 & \end{array}$

We now look at a series of probit equations in Table 5 that model the probability that an individual is self-employed in their main job. The numbers of controls are limited because of the need for comparability over time and countries - they include age, education, gender, household size and the number of children under the age of 15 in the household. I have also mapped onto the data file the gender-specific country unemployment rate for each year. I am unable to distinguish agricultural and non-agricultural employment in my data files currently. As we move across the columns the definition of the dependent variable is changed from a 1 if self-employed and a zero if an employee in column 1. Column 2 a zero also includes the unemployed and in column 3 those out of the labor force are added with the sample restricted to those individuals between the ages of 16 and 65 . Eighteen country dummies and the log of the unemployment rate plus a full set of interactions between the country dummies and the unemployment rate also included. Robust standard errors are estimated with an adjustment to allow for the so-called Moulton problem (Moulton, 1986, 1987, 1990) because unemployment rates relate to groups that have common components in their residuals; without such an adjustment standard errors would be biased downwards. For a discussion of this procedure see p.238 of Stata Release 5 User's Guide (1997) and Rogers (1993).

The probability of being self-employed rises with age, is higher for men than women and is higher the larger is household size. Interestingly the least educated (age left school < age 15) and the most educated (age left school >=22 years) have the highest probabilities of being self-employed. The 
time trend in all cases has a significant U-shape minimizing towards the end of the 1980s. When entered on its own without the country interactions the log of the unemployment rate is significantly positive in the first two columns and zero in the third (results not reported). The inclusion of the interaction terms in all three cases significantly improves the overall fit. Hence specifications with interactions are the ones reported. The coefficient on the unemployment rate refers to the US, which is not significantly different from zero in all three specifications. In column 1 significant negative effects are found in Austria, Denmark and Finland (based on a t-test of whether the overall effect for the country is significantly different from zero). On the other hand significant positive effects are found in Belgium, the United Kingdom, Germany, Norway and Sweden. No evidence of any effect from unemployment was found in France, Netherlands, Luxembourg, Greece, Spain and Portugal, These results are little changed as the measurement of the dependent variable, and hence the size of sample, is altered as we move across the columns.

In order to get a clearer picture of how the determinants of self-employment vary across countries I estimated a series of equations for each country. I also report results for Canada using a time series of cross sections of the Surveys of Consumer Finances for the years 1984-1995 (for details see the Data Appendix). Results are reported in Table 6. I exclude the unemployment rates as there are only two unemployment observations per year-one each for males and females. I group Austria, Finland, Norway and Sweden together as there are only two years of data available for each of these countries and include three country dummies. Analogously I combined East and West Germany and Great Britain and Northern Ireland. To examine the role of education two dummy variables, which distinguish the highest and lowest education categories, were also included. With only a couple of exceptions both the age and male variables are significantly positive. The results for the time trend, 
household size and the number of children are much more mixed across countries. Interestingly the findings in Table 8a are broadly confirmed; self-employment is highest for individuals at the tails of the education distribution. Individuals with the least education have the highest probability of being selfemployed which is consistent with the recent findings of Reardon (1998) for the USA. The main exception is the UK where the reverse is the case.

To conclude this section it appears that there is little consistent evidence that self-employment is correlated with unemployment consistently across countries. On balance there is probably more evidence in support of a negative effect but there is evidence of positive effects in a number of countries. Second, there is also a good deal of variation in the determinants of self-employment. Common to most countries is the fact that self-employment is dominantly male and more prevalent among older age groups than it is among the young (see Blanchflower and Oswald, 1998c for more on this). There is some evidence that self-employment is more prevalent among groups at the two ends of the education distribution and especially so for the least educated.

\section{Job satisfaction}

In this section I examine how satisfied the self-employed are with their jobs in comparison with employees. Questions about job satisfaction are difficult to interpret due to the subjective nature of the variable and the problem of making interpersonal comparisons (Freeman, 1978). Still, the econometric literature based upon satisfaction data has yielded interesting and consistent results across data sets that show links between satisfaction and economic and demographic variables. The small economics literature on this issue includes Hamermesh (1977), Borjas (1979), Freeman (1978), Meng (1990), Clark and Oswald (1992, 1996), Clark (1996), Blanchflower and Freeman (1996) and Blanchflower and Oswald (1999). Comparisons of responses to satisfaction questions across countries are fraught 
with even greater dangers, and we are aware of only one study making satisfaction comparisons across countries (Blanchflower and Freeman (1994) who compare job satisfaction in 10 countries). People in one country may "scale" responses differently than those in another. For instance, Americans may be relatively optimistic, with an "everything will work out" mentality that leads people with the same true satisfaction (on some objective scale) to respond more positively to a "Are you satisfied with your job?" question than the potentially more reserved British. Subject to these caveats it is not without interest to compare the satisfaction of the self-employed with that of employees.

In two earlier jointly authored papers paper I found that the self-employed reported being more satisfied with their jobs than was the case for employees. In Blanchflower and Oswald (1998a) we examined data for the UK from the National Child Development Study of 1981 for a sample of 23-year and found that the self-employed were more satisfied with their jobs ${ }^{13}$. Approximately $46 \%$ of the selfemployed said that they were in the top category of 'very satisfied', whereas the figure was $29 \%$ for employees. Ordered probit equations which also included controls for union membership, marital status, gender, disabled status, region, highest educational qualification, part-time, ever unemployed in the previous 5 years, a dummy for problems with arithmetic, months of experience, and job tenure confirmed this result. As an experiment into the effects of access to capital, we split the data into two sub-samples - those who had received no inheritance (the capital constrained) and those people who had received an kind of inheritance or gift - that we suggested might be considered to be less capital constrained. There is some evidence that the self-employment dummy variable had a smaller impact in

13 The question asked was "Taking everything into consideration, how satisfied or dissatisfied are you with your job as a whole" (Q19j, p.9: NCDS4 questionnaire). The responses were coded into five categories -- very dissatisfied, dissatisfied, neither, satisfied, and very satisfied. 
the group who inherited; the dummy even goes negative. Such evidence, we argued, might be taken to be consistent with the idea that those with capital—through an inheritance-are more able to enter the self-employment sector and drive down the rents available there.

In Blanchflower and Freeman (1997) a series of job satisfaction equations across 11 countries were estimated using data from the International Social Survey Programme of 1989 (for details see the Data Appendix) and found that the self-employed had higher levels of job satisfaction than employees in an equation where the countries were pooled ${ }^{14}$. Job satisfaction was especially low in Hungary. Table 7 reports levels of job satisfaction using these same data for the self-employed and employees and confirms the finding that the self-employed report higher levels of satisfaction than do employees in every country except Hungary. Table 8 reports the results of estimating an ordered logit with a full set of country dummies (Blanchflower and Freeman (1997) only included a Hungary dummy). The higher level of job satisfaction of the self-employed is confirmed. When separate equations by country were estimated (results not reported) the coefficient on self-employment is significantly positive in all countries except Ireland and Hungary where it is insignificantly different from zero.

New data on job satisfaction has recently become available for the 15 member countries of the European Union from one of the special supplements to the Eurobarometer Survey \#44.2 (available through ICPSR as survey \#6722) that was collected between November 1995 and 1996. The survey included a series of questions on working conditions that included a question on job satisfaction ${ }^{15}$. The

\footnotetext{
14 The question asked was "How satisfied are you in your main job?" (Q21 ISSP 1989 questionnaire). The responses were coded into seven categories -- completely dissatisfied, very dissatisfied, fairly dissatisfied, neither, fairly satisfied, very satisfied and completely satisfied.

15 The question asked was "on the whole, are you very satisfied, fairly satisfied, very satisfied or not at all satisfied with your main paid job? (Q36). These data were also examined by Blanchflower and Oswald (1999).
} 
weighted responses by country are tabulated in Table 9 separately for employees and the selfemployed. Despite the rather small sample sizes for the self-employed once again it appears to be true that the self-employed have higher levels of job satisfaction than those who are not their own boss. The only exception to this is Greece. The survey is rich in information on other aspects of the job which can be included in a job satisfaction in an attempt to distinguish the source of this higher level of satisfaction. In Table 10 ordered logit equations are estimated with job satisfaction as the dependent variable (1=not at all satisfied, $2=$ not very satisfied and so on) which include controls for industry, occupation, age and its square and gender in column 1 and confirm the finding that the self-employed have significantly higher levels of satisfaction than employees ( $t=7.8)$. In column 2 further controls for commuting time, job tenure, shift working, establishment size, and public sector are added and find the same self-employment result ( $\mathrm{t}=4.6)$. Reading from column 2, job satisfaction is $\mathrm{U}$-shaped in age; lower for those who work shifts, who work alone or are employed in agriculture or live in Greece. Job satisfaction is higher for legislators/managers; for those in public sector jobs, with longer job tenure, with shorter commuting time to their place of work and who live in Denmark. When column 1 is re-estimated separately for each country, the coefficient on the self-employment dummy is positive in every case. It has a t-statistic above 2 for 6 countries (Belgium, Germany, Italy, Luxembourg, Netherlands and Sweden), between 1.8 and 2 for a further three countries (Ireland, Great Britain and Finland) and 1.5 for Denmark. It is insignificantly different from zero in Greece, Spain, France, Portugal and Austria.

Data on job satisfaction is also available for the United States in the General Social Surveys for the years 1972-199816 and are shown below for the employed and self-employed.

Very A little Moderately Very $\quad$ N

\footnotetext{
16 There were no surveys in 1979, 1981, 1992 or 1995.
} 


$\begin{array}{lccccr} & \text { dissatisfied } & \text { dissatisfied } & \text { satisfied } & \text { satisfied } & \text { (unweighted) } \\ \text { Employees } & 4 & 10 & 40 & 46 & 19903 \\ \text { Self-employed } & 2 & 5 & 29 & 63 & 3044 \\ \text { N (unweighted) } & 827 & 2256 & 8785 & 11079 & \end{array}$

Job satisfaction levels for the self-employed are considerably higher than for employees. This result is confirmed in column 1 Table 11 with the sample pooled over 21 years of data (this is not a panel of individuals but a rolling cross-section and which includes age and its square, gender, race, hours of work, years of schooling plus a time trend in addition to a dummy for self-employment. The selfemployed report being more satisfied with their work than employees using this long time run of data for the United States. Indeed, this result is robust to the inclusion of per capita household in column 2 which leaves the size and significance of the self-employment variable essentially unchanged.

I conclude this section with a simple statement. The self-employed are more satisfied with their jobs than are individuals who work for somebody else.

\section{Labor Market Flexibility and Macro-economic Performance}

Over the last couple of decades many countries - and especially the United Kingdom and New Zealand - implemented reforms focused directly on the labor market. Such reforms were expected to improve the workings of the economy by changing the labor market: industrial relations laws that weakened union power; measures to enhance self-employment; privatization of government-run or owned businesses; reduction in the value of unemployment benefits and other social receipts relative to wages; new training initiatives; tax breaks to increase use of private pensions; lower marginal taxes on individuals; elimination of wage councils that set minimum wages. In the price-theorists' ideal world, these changes were intended to reduce market rigidities, increase mobility, and raise incentives. They were intended to create the micro-institutional base for a more effective market economy with higher 
productivity, lower unemployment, improved living standards, and possibly a higher permanent rate of economic growth as well. Unfortunately there is relatively little empirical evidence available to support these contentions and especially so in the case of entrepreneurship and self-employment ${ }^{17}$. Indeed, relatively little is known about the macro-economic correlates of self-employment.

Table 12 examines the relationship between the growth in real GDP, and changes in the selfemployment rate, using time series data on 23 countries for the period 1966-1996 (the countries are: Australia, Austria, Belgium, Canada, Denmark, Eire, Finland, France, Germany, Greece, Iceland, Italy, Japan, Luxembourg, Netherlands, New Zealand, Norway, Portugal, Spain, Sweden, Turkey, UK and the USA). The regressions should be thought of as a Cobb-Douglas production function, where the change in the numbers of employees over the previous period is included to distinguish the labor input. Capital is assumed to grow linearly and as the model is estimated in changes the effect of capital will be in the constant. Also included in the regressions are a set of country dummies plus a lagged dependent variable. The three columns experiment with different measures of the change in self-employment over the preceding period where the number of self-employed is expressed as a percentage of all workers in column 1; of the labor force in column 2 and the population age 16-64 in column 3. Increases in the proportion of self-employment appear to produce lower not higher GDP; this result is significant in columns 1 and 2 but not in 3 . These results presume a particular direction of causation - from selfemployment to growth and not the reverse, which is clearly a possibility—and are meant to be illustrative. Clearly more work is warranted on this question, but it certainly does not appear that more is better in this instance, contrary to the assertions of some.

17 For a discussion of the relative lack of success of the Thatcher labor market reforms in transforming the UK economy see Blanchflower and Freeman (1994). 
There seems to be a widely held belief that the self-employed are inherently more flexible and adaptable than are employees. Clearly their earnings tend to be more cyclically volatile than that of employees: small firms are continuously dying as others are being born. There is another aspect of flexibility that does not seem to have been considered - are the self-employed more or less mobile geographically than are employees? A recent sweep of the International Social Survey Programme (ISSP) conducted in 1995 asked respondents in 23 countries the following questions "if you could improve your work or living conditions, how willing or unwilling would you be to

- move to another neighbourhood (or village); Q2a

- move to another town or city within this (county): $Q 2 b$

- move to another region: $Q 2 c$

- move outside your country? Q2d

Possible responses were "very willing, fairly willing, neither willing nor unwilling, fairly willing and very unwilling"

Table 13 reports four ordered logit equations relating to each of these questions. The dependent variable is set to 1 if very unwilling and so on, hence a positive coefficient can be interpreted as indicating that the individual is more willing to move. The sample is restricted to 13 OECD countries (Austria, Canada, Ireland, Italy, Japan, Netherlands, New Zealand, Norway, Spain, Sweden, the UK and the USA). Information is also available on 7 ex-Communist countries (Hungary, Czech Republic, Slovenia, Bulgaria, Russia, Latvia and Slovakia) plus the Philippines but these countries were dropped. There is some evidence that males are more willing to move regions and country than are females - but there is no difference between the sexes by town or neighborhood. Being prepared to move is negatively correlated with age and years spent living in the current location and positively correlated with education, whether or not an individual had lived abroad and for how long. The unemployed seem to be more mobile than the other labor market groups. The self-employed appear to be less prepared to 
move neighborhood, town or region than are employees. This presumably arises because of the presence of a customer base for the self-employed along with business and personal contacts.

One possible interpretation of the coefficients on the country dummies reported in Table 13 would be as a flexibility index. This seemed an intriguing possibility, so in Part A of Table 14 I simply ranked the countries by the coefficient on the country dummy from the separate regressions in Table 13, for the sub-sample of OECD countries. Columns 1-3 relate to responses to questions on whether the individual was willing to move neighborhood, town or region respectively. The next to last column is the sum of the ranks in the first three columns and the next column is a rank ordering derived from these sums. I exclude from these calculations the information on whether an individual is prepared to move to another country as this is not strictly relevant to the task in hand. Americans are the most willing to move within their country followed closely by the Dutch, whose labor market has performed remarkably well over the last decade or $\mathrm{so}^{18}$. The Irish are the least mobile followed closely by the Italians and the Japanese. The last column is the proportion of the total population that is self-employed in 1996. The results here are intended to simply be suggestive but it should be noted that countries with a low proportion of self-employment appear to the most flexible, confirming our earlier results.

In an attempt to validate these results I re-estimated the equations in Table 13 but now with the full sample of countries which includes seven ex-communist countries and the Philippines (sample size now just under 24,000). The results are reported in Part B of Table 14. The results are slightly different from those reported in Part A for the OECD countries; the main difference is that now the US

18 The Dutch economy has had strong growth in employment over the last decade or so and unemployment perfomance has also been strong. It's (standardized) unemployment rate in 1996 was well below that of other European countries at 6.3\% (Source: OECD Economic Outlook, June 1998). This compares with 9.7\% in Belgium, 6.9\% in Denmark, $15.3 \%$ in Finland, $11.6 \%$ in Ireland, $8.2 \%$ in the UK, $8.9 \%$ in Germany, $12.4 \%$ in France and $12.0 \%$ in Italy. 
is ranked first, as the most flexible country, on all three measures, and Canada, Germany and the

Netherlands all rank equal second. Latvia and Russia are the least flexible followed by Hungary. The highest ranked ex-Communist country is Slovakia which ranks eleventh. Our only developing country, the Philippines, is in the middle of the pack ranking fourteenth. One of the considerable advantages of this measure of fexibility is that it seems to match closely most people's priors. It certainly matches them more closely than my earlier attempts to generate a wage flexibility index across countries by comparing how individual's wages are influenced by local area unemployment rates ${ }^{19}$.

\section{Conclusions}

The main conclusions are as follows.

1. The overall trend in self-employment, at the economy level in the years since 1966, has been down in most countries. The main exceptions to this are Portugal, New Zealand and the United Kingdom where the trend has been upward.

2. As a proportion of non-agricultural employment self-employment has declined in some countries (Austria, Belgium, Japan, Luxembourg, Netherlands, Norway, Spain and the USA) but increased in others (Australia, Canada, Finland, Iceland, Ireland, New Zealand, Portugal, Sweden and the United Kingdom).

3. For most countries there is a negative relationship between the self-employment rate (variously defined) and the unemployment rate. From the time series regressions evidence of positive effects is found only in Iceland and Italy. The effects are more strongly negative in the agricultural sector. There is more evidence of positive unemployment effects in the individual level equations.

4. The probability of being self-employed is higher among men than women and rises with age. The least educated have the highest probability of being self-employed, however, evidence is found that the most highly educated have relatively high probabilities.

5. The self-employed have higher levels of job satisfaction than employees.

19 There is now a large literature that estimates wage curves across countries. Interestingly most of the estimates of the so-called unemployment elasticity of pay which crowd closely around -0.1. That is a doubling of unemployment lowers wages by $10 \%$ almost everywhere. For a discussion see Blanchflower and Oswald $(1994,1996)$. 
6. I could find no evidence that increases in the self-employment rate increased the real growth rate of the economy.

7. The self-employed are less willing to move from their neighborhoods, towns and regions than are employees, presumably because of the pull of their customers.

8. I developed a flexibility index based on information provided by individuals in 1995 . According to this index the US economy was the most flexible, followed by Canada, Germany and the Netherlands. Latvia, Russia and Hungary were found to be the least flexible countries. Of the OECD countries examined, Austria and Ireland were ranked lowest. 
Table 1. Suppose you were working and could choose between different kinds of jobs. Which of the following would you choose? "Being an employee or being self-employed?" - \% reporting self-employed.

\begin{tabular}{lcccc} 
& \multicolumn{2}{c}{ All individuals } & \multicolumn{2}{c}{ Employees } \\
Austria & $\%$ & $\mathrm{~N}$ & $\%$ & $\mathrm{~N}$ \\
Great Britain & 60 & 1779 & 56 & 724 \\
Hungary & 48 & 1183 & 43 & 600 \\
Ireland & 38 & 494 & 560 \\
Israel & 51 & 944 & 50 & 379 \\
Italy & 49 & 410 & 64 & 477 \\
Netherlands & 65 & 1489 & 33 & 387 \\
Northern Ireland & 39 & 705 & 47 & 379 \\
Norway & 52 & 1589 & 22 & 266 \\
USA & 26 & 1283 & 59 & 970 \\
West Germany & 63 & 1207 & 47 & 693 \\
& 49 & & 474
\end{tabular}

Source: International Social Survey Programme, 1989 
Table 2. Self-employment as a \% of all employment

$\begin{array}{lcccc} & 1966 & 1976 & 1986 & 1996 \\ \text { Australia } & 15.9 & 15.2 & 16.8 & 15.1^{\mathrm{i}} \\ \text { Austria } & 27.8^{\mathrm{a}} & 19.2 & 14.8 & 13.7^{\mathrm{i}} \\ \text { Belgium } & 21.9 & 16.7 & 18.1 & 18.4^{\mathrm{d}} \\ \text { Canada } & 14.8 & 9.7 & 9.7 & 11.3 \\ \text { Denmark } & 22.5^{\mathrm{b}} & 16.8 & 11.6 & 9.5 \\ \text { Finland } & 29.6 & 20.2 & 14.9 & 14.5^{\mathrm{c}} \\ \text { France } & 25.1 & 17.8 & 15.8 & 11.6^{\mathrm{c}} \\ \text { Germany } & 19.1 & 13.6 & 11.5 & 10.6^{\mathrm{c}} \\ \text { Greece } & \mathrm{n} / \mathrm{a} & 52.4^{\mathrm{e}} & 50.7 & 46.1^{\mathrm{c}} \\ \text { Iceland } & 18.0 & 15.1 & 13.5 & 18.2^{2} \\ \text { Ireland } & 34.4 & 28.3 & 23.4 & 20.9 \\ \text { Italy } & 37.4 & 24.1 & 29.9 & 28.9 \\ \text { Japan } & 38.0 & 29.4 & 24.9 & 17.7 \\ \text { Luxembourg } & 22.4 & 15.4 & 11.3 & 7.6^{\mathrm{c}} \\ \text { Netherlands } & 18.5 & 12.7 & 11.3 & 12.5 \\ \text { New Zealand } & 14.0 & 14.1 & 17.9 & 20.4 \\ \text { Norway } & 22.5 & 14.8 & 12.7 & 8.7 \\ \text { Portugal } & 25.9 & 35.2 & 31.3 & 28.7 \\ \text { Spain } & 36.8^{\mathrm{g}} & 31.5 & 30.0 & 25.0 \\ \text { Sweden } & 13.1^{\mathrm{g}} & 8.2 & 6.5 & 11.0 \\ \text { Turkey } & \mathrm{n} / \mathrm{a} & \mathrm{n} / \mathrm{a} & 58.5^{\mathrm{f}} & 58.3 \\ \text { UK } & 6.7 & 8.0 & 11.5 & 13.6 \\ \text { USA } & 12.7 & 9.3 & 8.9 & 8.4\end{array}$

Notes $\mathrm{a}=1969 ; \mathrm{b}=1967 ; \mathrm{c}=1995 ; \mathrm{d}=1992 ; \mathrm{e}=1977 ; \mathrm{f}=1988 ; \mathrm{g}=1968 ; \mathrm{h}=1979 ; \mathrm{i}=1994$

Source: OECD Labour Force Statistics (various). 
Table 3. Self-employment as a \% of all non agricultural employment.

$\begin{array}{lcccc} & 1966 & 1976 & 1986 & 1996 \\ \text { Australia } & 9.8 & 10.1 & 11.8 & 11.3 \\ \text { Austria } & 11.5^{\mathrm{a}} & 8.7 & 7.4^{\mathrm{i}} & 7.4 \\ \text { Belgium } & 14.8 & 12.3 & 13.8 & 14.4^{\mathrm{d}} \\ \text { Canada } & 8.3 & 6.2 & 6.9 & 8.9 \\ \text { Denmark } & 12.9^{\mathrm{b}} & 10.4 & 7.7 & 7.2 \\ \text { Finland } & 7.6 & 7.4 & 6.6 & 9.1 \\ \text { France } & 12.5 & 9.8 & 9.5 & 7.8 \\ \text { Germany } & 10.0 & 8.1 & 7.7 & 8.3 \\ \text { Greece } & - & 23.6^{\mathrm{e}} & 24.6 & 25.1^{\mathrm{c}} \\ \text { Iceland } & 9.0 & 7.7 & 8.6 & 13.2 \\ \text { Ireland } & 9.6 & 10.2 & 10.4 & 11.7 \\ \text { Italy } & 20.8 & 14.1 & 20.5 & 20.8 \\ \text { Japan } & 18.3 & 17.1 & 15.8 & 12.0 \\ \text { Luxembourg } & 11.8 & 9.0 & 7.6 & 5.4^{\mathrm{c}} \\ \text { Netherlands } & 11.6 & 8.2 & 7.6 & 9.6 \\ \text { New Zealand } & - & - & 12.1 & 14.5 \\ \text { Norway } & 8.7 & 7.6 & 7.1 & 5.4 \\ \text { Portugal } & 13.1 & 12.5 & 14.5 & 17.3 \\ \text { Spain } & 18.2 & 16.8 & 18.4 & 17.4 \\ \text { Sweden } & 7.0^{\mathrm{b}} & 4.4 & 4.1 & 8.5 \\ \text { Turkey } & - & - & 21.9^{\mathrm{f}} & 22.8 \\ \text { UK } & 5.3 & 6.6 & 9.6 & 11.3 \\ \text { USA } & 8.6 & 6.8 & 7.1 & 6.8\end{array}$

Notes $a=1969 ; b=1967 ; c=1995 ; d=1992 ; \mathrm{e}=1977 ; \mathrm{f}=1988 ; \mathrm{g}=1968 ; \mathrm{h}=1979 ; \mathrm{i}=1994$ Source: OECD Labour Force Statistics (various). 
Table 4. Self-employment regressions, 1966-1996.

\begin{tabular}{|c|c|c|c|c|c|}
\hline & Self & Self1 & Self2 & Self3 & Self4 \\
\hline Self $_{t-1}$ & $.3606(11.88)$ & $.7435(33.66)$ & .3188 (9.79) & $.5742(17.05)$ & $.8177(36.46)$ \\
\hline$\%$ Agriculture & $.4469(16.32)$ & .1334 (8.56) & $.2251 \quad(9.95)$ & .1025 (4.42) & $-.0130 \quad(0.33)$ \\
\hline Time & $.0008 \quad(5.05)$ & $.0002 \quad(2.42)$ & $.0004 \quad(3.40)$ & $.0006 \quad(4.26)$ & $-.0011(4.08)$ \\
\hline Unemployment rate & $-.0190 \quad(3.00)$ & $-.0058(1.62)$ & $-.0182 \quad(3.57)$ & -.0106 (1.79) & .0124 (1.34) \\
\hline Belgium*unemployment rate & $.0164 \quad(2.28)$ & .0055 (1.39) & .0118 (2.04) & $.0096 \quad(1.42)$ & $-.0068 \quad(0.63)$ \\
\hline Denmark*unemployment rate & $.0056 \quad(0.81)$ & $-.0001(0.04)$ & $.0052(0.93)$ & $.0022 \quad(0.34)$ & $-.0295(2.84)$ \\
\hline Finland*unemployment rate & .0294 (4.17) & $.0072(1.86)$ & $.0139(2.47)$ & $.0199(2.96)$ & $-.0102(0.98)$ \\
\hline Greece*unemployment rate & .0249 (2.93) & $.0012 \quad(0.27)$ & $.0185 \quad(2.71)$ & .0153 (1.91) & $-.0045 \quad(0.35)$ \\
\hline Ireland*unemployment rate & .0322 (3.99) & $.0044(1.00)$ & $.0040 \quad(0.62)$ & $.0262 \quad(3.38)$ & $-.0000 \quad(0.00)$ \\
\hline Lux*unemployment rate & $.0085 \quad(1.23)$ & $.0021 \quad(0.56)$ & .0109 (1.94) & $.0040 \quad(0.61)$ & $-.0196(1.88)$ \\
\hline Norway*unemployment rate & .0077 (1.07) & $.0001 \quad(0.04)$ & $.0096 \quad(1.65)$ & $.0040 \quad(0.59)$ & $-.0202(1.87)$ \\
\hline Portugal*unemployment rate & $.0128 \quad(1.26)$ & $-.0226(3.97)$ & $-.0572(7.11)$ & $.0106 \quad(1.15)$ & $-.0661 \quad(4.48)$ \\
\hline Spain*unemployment rate & .0264 (4.01) & $.0034 \quad(0.95)$ & $.0106 \quad(2.03)$ & .0134 (2.18) & $-.0069(0.72)$ \\
\hline Canada*unemployment rate & $.0084 \quad(0.81)$ & .0058 (1.02) & $.0141 \quad(1.68)$ & $.0082 \quad(0.84)$ & $-.0356(2.16)$ \\
\hline Japan*unemployment rate & -.0205 (2.16) & $-.0124 \quad(2.37)$ & $-.0223(2.82)$ & $-.0161 \quad(1.80)$ & $-.0014(0.10)$ \\
\hline Australia*unemployment rate & $.0277 \quad(3.78)$ & $.0085 \quad(2.04)$ & $.0228 \quad(3.89)$ & $.0147 \quad(2.14)$ & $-.0002(0.02)$ \\
\hline NZ*unemployment rate & $.0261 \quad(2.34)$ & $.0085 \quad(1.37)$ & $.0231 \quad(2.57)$ & $.0261 \quad(2.45)$ & $-.0488 \quad(2.88)$ \\
\hline France* unemployment rate & $.0058 \quad(0.82)$ & $.0005 \quad(0.15)$ & $.0028 \quad(0.49)$ & $.0005 \quad(0.08)$ & $-.0049(0.46)$ \\
\hline Iceland*unemployment rate & $.0351 \quad(5.08)$ & $.0119(3.01)$ & $.0322 \quad(5.75)$ & $.0206 \quad(3.17)$ & $-.0073(0.74)$ \\
\hline Italy*unemployment rate & $.0813 \quad(7.79)$ & $.0252 \quad(4.38)$ & $.0392(4.58)$ & $.0469 \quad(4.79)$ & $.0092(0.61)$ \\
\hline Neths*unemployment rate & $.0036 \quad(0.51)$ & $-.0000(0.02)$ & $.0087 \quad(1.53)$ & $-.0000 \quad(0.00)$ & $-.0148(1.41)$ \\
\hline Sweden*unemployment rate & $.0291 \quad(3.71)$ & $.0098 \quad(2.22)$ & $.0214 \quad(3.41)$ & $.0163 \quad(2.21)$ & $.0057 \quad(0.50)$ \\
\hline Turkey*unemployment rate & $.0977 \quad(2.21)$ & $.0478 \quad(1.97)$ & $.0766 \quad(2.14)$ & .0827 (1.99) & $.0303(0.45)$ \\
\hline Germany*unemployment rate & $.0120 \quad(1.80)$ & $.0033 \quad(0.91)$ & $.0094 \quad(1.75)$ & .0066 (1.06) & $-.0208(2.08)$ \\
\hline UK* unemployment rate & $.0312(4.08)$ & $.0107 \quad(2.46)$ & $.0263 \quad(4.32)$ & $.0171 \quad(2.39)$ & $.0181 \quad(1.60)$ \\
\hline USA*unemployment rate & $.0140 \quad(1.24)$ & .0065 (1.05) & .0156 (1.71) & $.0080 \quad(0.75)$ & $-.0225(1.32)$ \\
\hline Constant & $.0380 \quad(3.75)$ & $.0187 \quad(3.04)$ & $.0465 \quad(5.90)$ & $.0193 \quad(2.05)$ & $.1684 \quad 6.20)$ \\
\hline $\mathrm{N}$ & 600 & 600 & 591 & 600 & 600 \\
\hline
\end{tabular}




$\begin{array}{lrrrrr}\text { Adjusted R } & .9860 & .9949 & .9706 & .9686 & .9842 \\ \text { F } & 810.6 & 2259.7 & 372.5 & 354.1 & 716.2\end{array}$

Notes: Self=self employment/total employment; Self1=self employment/labor force; Self2= self employment/ population; Self3=(selfemployed/all workers) - non-agricultural; Self4=(self-employed/all workers) - agricultural. Unemployment rate is everywhere in natural logarithms. Excluded country is Austria. Equations also include a full set of country dummies. 
Table 5. Micro self-employment equations, 1975-1996 (Ages 16-64)

$\begin{array}{ccc}\text { Self employed/ } & \begin{array}{c}\text { Self employed/ } \\ \text { Labour force }\end{array} & \begin{array}{c}\text { Self employed/ } \\ \text { Population } \\ \text { Age 16-64 }\end{array}\end{array}$

Age

(1) (2)

(3)

Male

ALS 15

$.0055(42.50) \quad .0053(46.46) \quad .0016(18.37)$

ALS 16

$\begin{array}{lllll}.0573 & (7.66) \quad .0519 & (7.57) \quad .1035(19.20)\end{array}$

$\begin{array}{llllll}-.0416 & (8.63) & -.0356 & (7.84) & -.0150 & (4.89)\end{array}$

ALS 17

$-.0428(8.06)$

$-.0332(6.63)$

$-.0142$

(4.19)

ALS 18

-.0422 (8.12)

-.0290 (5.80)

$-.0086 \quad(2.51)$

ALS 19

-.0415 (8.66)

-.0286 (6.07)

$-.0043 \quad(1.28)$

ALS 20

$-.0370(6.25)$

-.0244 (4.26)

.0033

(0.85)

ALS 21

-.0389 (5.98)

-.0238 (3.80)

$.0070 \quad(1.52)$

ALS $>=22$

-.0335 (4.46)

-.0169 (2.35)

$.0130 \quad(2.36)$

Time

Time $^{2}$

Household size

$-.0216(3.65) \quad-.0066 \quad(1.16)$

$.0242 \quad(5.67)$

$\begin{array}{lllll}-.0092 & (4.39) & -.0084 & (4.40)\end{array}$

$-.0070$

$(5.21)$

$.0004 \quad(3.97) \quad .0003 \quad(3.86)$

$.0003 \quad(4.96)$

$\begin{array}{llllll}.0099 & (6.76) & .0084 & (6.42) & .0056 & (6.36)\end{array}$

\# children $<15$

Unemployment rate

$-.0025(2.01)$

$-.0000 \quad(0.08)$

$.0009 \quad(1.13)$

France* unemployment rate

Belgium* unemployment rate

Netherlands* unemployment rate

$\begin{array}{lllll}-.0104 & (0.32) & -.0199 & (0.69)\end{array}$

$-.0186 \quad(0.76)$

$\begin{array}{lllll}-.0056 & (0.15) \quad .0330 & (1.05)\end{array}$

$.0103 \quad(0.39)$

$.0904 \quad(2.58)$

.0799 (2.67)

.0551

(2.11)

.0389 (1.02) .0396 (1.15)

$.0237 \quad(0.84)$

West Germany* unemployment rate

$.1121(2.13)$

.1025 (2.17)

$.0838 \quad(2.43)$

Italy* unemployment rate

$.0376(1.08)$

.0313 (1.04)

$.0073 \quad(0.29)$

Luxembourg* unemployment rate

$.0123(0.34)$

$.0227(0.73)$

$.0148 \quad(0.58)$

Denmark* unemployment rate

Ireland* unemployment rate

Great Britain* unemployment rate

$\mathrm{N}$. Ireland* unemployment rate

Greece* unemployment rate

Spain* unemployment rate

Portugal* unemployment rate

East Germany* unemployment rate

Norway* unemployment rate

Finland* unemployment rate

Sweden* unemployment rate

Austria* unemployment rate

$-.1104(2.33)$

$-.1069(2.49)$

$-.0354 \quad(1.14)$

.0780 (1.83)

.0658 (1.79)

$.0785 \quad(2.34)$

$\begin{array}{llllll}.0801 & (2.26) & .0724 & (2.35) & .0437 & (1.66)\end{array}$

$\begin{array}{llllll}.1160 & (2.89) & .0944 & (2.76) & .0663 & (2.36)\end{array}$

$\begin{array}{llllll}.0460 & (1.09) & .0396 & (1.06) & -.0216 & (0.75)\end{array}$

$\begin{array}{llllll}.0496 & (1.21) & .0498 & (1.41) & .0088 & (0.27)\end{array}$

$\begin{array}{lllllll}-.0135 & (0.32) & -.0150 & (0.38) & .0038 & (0.13)\end{array}$

$\begin{array}{llllll}.1275 & (2.19) & .0850 & (1.74) & .1183 & (3.03)\end{array}$

$\begin{array}{llllll}.3811 & (4.79) & .3425 & (5.04) & .0659 & (1.44)\end{array}$

$\begin{array}{llllll}-1.1833 & (6.67) & -1.0446 & (6.43) & .7290 & (5.88)\end{array}$

$.9530(12.74) \quad .8888(13.09) \quad .1851 \quad$ (3.66)

$\begin{array}{llllll}-1.0091 & (2.46) & -.6647 & (1.77) & -1.7268 & (6.22)\end{array}$

N

$\mathrm{Chi}^{2}$

Pseudo-R ${ }^{2}$
255147

728576.0

.0940
283762

1066748

.0931
393924

700301.9

.0767 
Notes; excluded categories; USA, age left school $<=14$ years. Unemployment rate is measured in natural logarithms. Sample consists of the self-employed plus employees (columns $1 \& 2$ ); the unemployed are also included in the zeroes in columns $3 \& 4$ and those who are Out of the Labour Force (OLF) are added in columns $5 \& 6$. Method of estimation is dprobit in STATA. Standard errors adjusted for common components in the residuals.

Source: Eurobarometer Surveys and General Social Survey, 1975-1996 
Table 6. Self-employment regressions by country (Ages 16-64).

(Dependent variable: $1=$ self-employed; zero =employee).

\begin{tabular}{|c|c|c|c|c|c|c|c|c|}
\hline & $\begin{array}{c}\text { Low } \\
\text { Education }\end{array}$ & $\begin{array}{c}\text { High } \\
\text { Education }\end{array}$ & Age & Male & H'hold size & \# children & Time & $\mathrm{N}$ \\
\hline All countries & .05 & .01 & + & + & + & - & + & 262714 \\
\hline USA & $.02 *$ & .02 & + & + & 0 & 0 & + & 18574 \\
\hline France & .05 & $.01 *$ & + & + & + & - & 0 & 21982 \\
\hline Belgium & $-.01 *$ & .04 & + & - & - & - & - & 20705 \\
\hline Netherlands & $-.01 *$ & .03 & + & + & + & 0 & 0 & 19573 \\
\hline Germany & .02 & .04 & + & + & + & - & + & 30151 \\
\hline Italy & .10 & $.00 *$ & + & + & 0 & - & + & 21725 \\
\hline Luxembourg & .08 & -.03 & + & 0 & + & 0 & + & 9181 \\
\hline Denmark & .05 & -.03 & + & + & + & 0 & + & 26002 \\
\hline Ireland & $.00 *$ & .04 & + & + & - & - & - & 18910 \\
\hline United Kingdom & -.05 & .11 & + & + & - & + & + & 28199 \\
\hline Greece & .19 & $.00 *$ & + & + & + & - & - & 15399 \\
\hline Spain & .02 & $.02 *$ & + & + & 0 & 0 & + & 9947 \\
\hline Portugal & .09 & .03 & + & + & + & 0 & + & 14316 \\
\hline $\begin{array}{l}\text { Norway, Austria, } \\
\text { Finland \& Sweden }\end{array}$ & $.03 *$ & $-.01 *$ & + & + & + & - & $\mathrm{n} / \mathrm{a}$ & 8050 \\
\hline Canada & .05 & -.02 & + & + & $\mathrm{n} / \mathrm{a}$ & + & + & 577911 \\
\hline
\end{tabular}

Notes; method of estimation dprobit. Equation for Austria, Sweden, Norway and Finland contains no time trend as data available only for 1995/6. Regressions for Canada also include 10 province dummies and five family status variables (see Table 8a). Low education defined as age left school $<=14$ years. High education defined as age left school $>=22$ years in all countries except Canada where they are defined as $<=8$ years of schooling and at least a degree. $*=$ insignificantly different from zero at the $5 \%$ level on a 2 -tailed test. 
Source: Eurobarometer Surveys, Surveys of Consumer Finances (Canada, 1981-1995) and General Social Survey (USA). 
Table 7. Job Satisfaction, 1989.

$\begin{array}{lccccc} & \text { Other* } & \begin{array}{c}\text { Fairly } \\ \text { Satisfied }\end{array} & \begin{array}{c}\text { Very } \\ \text { Satisfied }\end{array} & \begin{array}{c}\text { Completely } \\ \text { Satisfied }\end{array} & \text { N } \\ \text { a) Employees } & & & & & \\ \text { West Germany } & 17 & 43 & 32 & 8 & 578 \\ \text { UK } & 16 & 47 & 27 & 10 & 856 \\ \text { USA } & 13 & 39 & 35 & 13 & 694 \\ \text { Austria } & 15 & 40 & 29 & 16 & 721 \\ \text { Hungary } & 23 & 64 & 6 & 6 & 524 \\ \text { Netherlands } & 16 & 46 & 29 & 9 & 603 \\ \text { Italy } & 20 & 50 & 16 & 14 & 402 \\ \text { Ireland } & 10 & 39 & 34 & 17 & 375 \\ \text { Norway } & 15 & 44 & 28 & 13 & 982 \\ \text { Israel } & 15 & 50 & 25 & 10 & 559 \\ \text { All } & 16 & 46 & 27 & 12 & 6296\end{array}$

b) Self-employed

West Germany

UK

USA

$\begin{array}{rrrrr}4 & 22 & 57 & 17 & 67 \\ 5 & 41 & 27 & 27 & 133 \\ 8 & 25 & 36 & 31 & 96 \\ 9 & 34 & 31 & 25 & 86 \\ 31 & 51 & 11 & 6 & 35 \\ 5 & 40 & 38 & 17 & 42 \\ 17 & 40 & 20 & 23 & 174 \\ 6 & 45 & 26 & 23 & 95 \\ 18 & 36 & 25 & 21 & 66 \\ 10 & 46 & 28 & 16 & 114 \\ 11 & 38 & 29 & 22 & 908\end{array}$

Notes: * "Other" includes "neither", "fairly dissatisfied", "very dissatisfied" and "completely dissatisfied". 
Sample restricted to workers only; all estimates are weighted.

Source: International Social Survey Programme, 1989 
Table 8. Job Satisfaction Ordered Logit, 1989

\begin{tabular}{lcc} 
& \multicolumn{2}{c}{$(1)$} \\
Self-employed & .4673 & $(5.49)$ \\
Age & .0187 & $(9.05)$ \\
Male & -.1996 & $(4.08)$ \\
Union member & -.1788 & $(3.49)$ \\
Austria & .2017 & $(2.02)$ \\
Great Britain & -.1623 & $(1.56)$ \\
Hungary & -.9503 & $(8.92)$ \\
Ireland & .3963 & $(3.48)$ \\
Italy & $-.3932-$ & $(3.24)$ \\
Netherlands & -.0535 & $(0.51)$ \\
Northern Ireland & .0659 & $(0.51)$ \\
Norway & .0503 & $(0.53)$ \\
USA & .2203 & $(2.02)$ \\
& & \\
cut1 & & \\
cut2 & -4.7354 & \\
cut3 & -3.7690 & \\
cut4 & -2.4286 & \\
cut5 & -1.2552 & \\
cut6 & .93334 & \\
N & 2.5106 & \\
Chi & \\
Pseudo R & & \\
Log Likelihood & \multicolumn{2}{c}{6053} \\
\end{tabular}

Notes: excluded category West Germany. Sample consists of workers only. (Source: International Social Survey Programme, 1989) 
Table 9. Job Satisfaction, 1995-1996

\begin{tabular}{|c|c|c|c|c|c|}
\hline & $\begin{array}{l}\text { Not at all } \\
\text { Satisfied }\end{array}$ & $\begin{array}{l}\text { Not very } \\
\text { satisfied }\end{array}$ & $\begin{array}{l}\text { Fairly } \\
\text { satisfied }\end{array}$ & $\begin{array}{l}\text { Very } \\
\text { satisfied }\end{array}$ & $\mathrm{N}$ \\
\hline \multicolumn{6}{|l|}{ a) Employees. } \\
\hline Belgium & 1 & 6 & 52 & 41 & 775 \\
\hline Denmark & 2 & 3 & 45 & 49 & 919 \\
\hline West Germany & 5 & 11 & 52 & 32 & 889 \\
\hline Greece & 6 & 25 & 56 & 13 & 526 \\
\hline Italy & 5 & 18 & 57 & 20 & 727 \\
\hline Spain & 4 & 17 & 57 & 23 & 757 \\
\hline France & 5 & 14 & 61 & 20 & 862 \\
\hline Ireland & 1 & 5 & 39 & 55 & 775 \\
\hline Luxembourg & 2 & 6 & 57 & 35 & 418 \\
\hline Netherlands & 1 & 7 & 47 & 44 & 962 \\
\hline Portugal & 3 & 14 & 62 & 21 & 696 \\
\hline Great Britain & 5 & 9 & 49 & 37 & 925 \\
\hline East Germany & 2 & 9 & 57 & 33 & 927 \\
\hline Finland & 2 & 5 & 63 & 31 & 903 \\
\hline Sweden & 2 & 6 & 55 & 37 & 967 \\
\hline Austria & 1 & 9 & 47 & 43 & 937 \\
\hline Euro 15 & 4 & 12 & 54 & 30 & 12965 \\
\hline \multicolumn{6}{|c|}{ b) self-employed } \\
\hline Belgium & 0 & 5 & 41 & 54 & 233 \\
\hline Denmark & 0 & 0 & 39 & 61 & 73 \\
\hline West Germany & 2 & 11 & 39 & 49 & 135 \\
\hline Greece & 13 & 34 & 44 & 10 & 476 \\
\hline Italy & 2 & 7 & 53 & 39 & 301 \\
\hline Spain & 3 & 14 & 58 & 26 & 239 \\
\hline France & 8 & 12 & 52 & 28 & 126 \\
\hline Ireland & 0 & 2 & 31 & 67 & 229 \\
\hline Luxembourg & 1 & 2 & 34 & 62 & 71 \\
\hline Netherlands & 1 & 1 & 39 & 59 & 101 \\
\hline Portugal & 2 & 12 & 63 & 23 & 299 \\
\hline Great Britain & 3 & 4 & 47 & 46 & 137 \\
\hline East Germany & 2 & 8 & 49 & 41 & 119 \\
\hline Finland & 2 & 10 & 56 & 32 & 150 \\
\hline Sweden & 0 & 3 & 34 & 63 & 88 \\
\hline Austria & 2 & 9 & 38 & 52 & 128 \\
\hline Euro 15 & 3 & 10 & 48 & 38 & 2905 \\
\hline
\end{tabular}

Notes: sample consists of the employed. All estimates are weighted. 
Source: Eurobarometer \#44.2. Working conditions in the European Union, November 1995-January 1996. 
Table 10. Job Satisfaction Ordered Logit, 1995-1996

\begin{tabular}{|c|c|c|c|c|}
\hline Self-employed & .3663 & $(7.82)$ & .3003 & $(4.61)$ \\
\hline Age & -.0139 & $(1.63)$ & -.0193 & $(1.89)$ \\
\hline $\mathrm{Age}^{2}$ & .0002 & $(2.20)$ & .0002 & $(2.04)$ \\
\hline Male & -.0177 & $(0.51)$ & .0047 & $(0.12)$ \\
\hline 16-19 years schooling & .0834 & $(1.87)$ & .1112 & $(2.26)$ \\
\hline$>=20$ years schooling & .1473 & $(2.86)$ & 1994 & $(3.47)$ \\
\hline Mining and quarrying/Manufacturing & $(0.66)$ & .0375 & $(0.22)$ & \\
\hline Electricity, gas and water supply & .4375 & $(2.24)$ & .2184 & $(1.01)$ \\
\hline Construction & .1142 & $(0.74)$ & .0000 & $(0.00)$ \\
\hline Wholesale and retail trade, repairs & .1829 & $(1.24)$ & .0665 & $(0.39)$ \\
\hline Hotels and restaurants & .1049 & $(0.64)$ & -.0163 & $(0.08)$ \\
\hline Transportation and communication & .2096 & $(1.34)$ & .1321 & $(0.74)$ \\
\hline Financial intermediation & .1373 & $(0.82)$ & .0015 & $(0.00)$ \\
\hline Real estate and business activities & .2500 & $(1.56)$ & .1403 & $(0.77)$ \\
\hline Public administration & .4142 & $(2.75)$ & .2869 & $(1.66)$ \\
\hline Other services & .3276 & $(2.24)$ & .2246 & $(1.35)$ \\
\hline Professionals & -.0556 & $(0.72)$ & -.0693 & $(0.81)$ \\
\hline Technicians & -.1323 & $(1.80)$ & -.1286 & $(1.60)$ \\
\hline Clerks & -.2418 & $(3.38)$ & -.2778 & $(3.55)$ \\
\hline Service and sales workers & -.3076 & $(4.31)$ & -.3309 & $(4.17)$ \\
\hline Agricultural and fishery workers... & -.7937 & $(4.81)$ & -1.0178 & $(5.40)$ \\
\hline Craft and related trades workers & -.4314 & $(6.13)$ & -.4560 & $(5.85)$ \\
\hline Plant and machine operators & -.6275 & $(7.26)$ & -.5924 & $(6.26)$ \\
\hline Elementary occupations & -.6880 & $(9.18)$ & -.7001 & $(8.30)$ \\
\hline Armed forces & -.2595 & $(1.34)$ & -.1234 & $(0.59)$ \\
\hline Commuting time & & & -.0024 & $(4.64)$ \\
\hline Job tenure & & & .0075 & $(3.22)$ \\
\hline Works irregular hours, but not in a shift & & & -.1975 & $(4.27)$ \\
\hline 2 shifts & & & -.2759 & $(3.79)$ \\
\hline 3 shifts & & & -.2412 & $(2.62)$ \\
\hline Yes, 4 shifts & & & -.2724 & $(1.39)$ \\
\hline Yes, 5 shifts and over & & & -.1149 & $(0.63)$ \\
\hline DK shift type & & & -.2386 & $(1.00)$ \\
\hline 1 to 9 employees & & & .3805 & $(5.08)$ \\
\hline 10 to 49 employees & & & .3042 & $(3.57)$ \\
\hline 50 to 99 employees & & & .1987 & $(1.99)$ \\
\hline 100 to 499 employees & & & .1459 & $(1.59)$ \\
\hline$>=500$ & & & .1419 & $(1.67)$ \\
\hline DK \# employees & & & .1539 & $(1.46)$ \\
\hline Public sector & & & .1298 & $(2.56)$ \\
\hline
\end{tabular}




$\begin{array}{lcc}\text { cut1 } & -4.2469 & -4.42320 \\ \text { cut2 } & -2.6081 & -2.7268 \\ \text { cut3 } & .15071 & .0982 \\ & & \\ \mathrm{~N} & 15870 & 13103 \\ \mathrm{Chi}^{2} & 1743.56 & 1511.30 \\ \text { Pseudo R } & \\ \text { Log Likelihood } & 0.0527 & .0557 \\ & -15662.0 & -12814.0\end{array}$

Notes: excluded categories - works alone; doesn't work shifts; agriculture; legislators/managers; Belgium; <=15yrs school.

(Source: Eurobarometer \#44.2. Working conditions in the EU, 1995-Jan 1996).

Equations also include a full set of country dummies. 
Table 11. Job Satisfaction Ordered Logit, USA, 1972-1998.

(1)

.5148 (12.47)

$.0260(24.46)$

-.1393 (5.13)

$-.3960(10.40)$

-.1561 (2.14)

.0358 (7.50)

$-.0116(6.58)$

$.0082(8.52)$

Hours

Income per head $* 10^{5}$

Region dummies (8)

cut1

cut2

cut3

$\mathrm{N}$

$\mathrm{Chi}^{2}$

Pseudo $\mathrm{R}^{2}$

Log Likelihood
Yes

$-1.7516$

$-.3134$

21943

1207.6

.0258

$-22801.9$
1.6992
(2)

.4837 (11.26)

$.0240(21.13)$

-.1667 (5.92)

$-.4052(9.80)$

-.1476 (1.93)

$.0266(5.13)$

$-.0170(8.59)$

$.0079(7.85)$

$.9590(7.10)$

Yes

$-1.9171$

$-.4794$

1.5357

20568

1162.0

.0265

$-21366.2$

Notes: excluded categories - white

Source: General Social Surveys, 1972-1998. 
Table 12. Growth in real GDP regressions, 1966-1996

(1)

Self $_{\mathrm{t}}-$ Self $_{\mathrm{t}-1}$

Self1 ${ }_{\mathrm{t}}-$ Self $_{\mathrm{t}-1}$

Self $2_{\mathrm{t}}-\operatorname{Self} 2_{\mathrm{t}-1}$

$\mathrm{GDP}_{\mathrm{t}-1}$

Empt $_{\mathrm{t}}-$ Empt $_{\mathrm{t}-1}$

$\mathrm{N}$

$\mathrm{R}^{2}$

F

618

.1922

5.88
(2)

(3)
$.3206(8.32) \quad .3332(8.76) \quad .3440(8.87)$

$\begin{array}{lll}-.0000(0.79) \quad .0000(.053) \quad .0000(0.50) & .000\end{array}$
$-10.3710(1.61)$

$-29.3480(2.51)$

.000 (.053) $-.000(0.50)$

$\begin{array}{rc}609 & 609 \\ .1913 & .1828 \\ 5.44 & 5.84\end{array}$

All equations include 22 country dummies. T-statistics in parentheses. Self-employment rates defined as in Table 7 above. Dependent variable =real GDP growth rate.

Source real growth rates OECD Economic Outlook (various issues). 
Table 13. Willingness to move, 1995

\begin{tabular}{|c|c|c|c|c|c|c|c|c|}
\hline \multirow[b]{2}{*}{ Self-employed } & \multicolumn{2}{|c|}{ Neighborhoods } & \multicolumn{2}{|c|}{ Town } & \multicolumn{2}{|c|}{ Region } & \multicolumn{2}{|c|}{ Country } \\
\hline & -.1382 & $(2.65)$ & -.1280 & $(2.44)$ & -.0910 & $(1.74)$ & .0115 & $(0.21)$ \\
\hline Unpaid family worker & -.3772 & $(2.13)$ & -.2157 & $(1.21)$ & -.2114 & (1.16) & .0959 & $(0.47)$ \\
\hline Unemployed & .2204 & $(3.02)$ & .2062 & $(2.85)$ & .1526 & $(2.10)$ & -.0578 & $(0.75)$ \\
\hline Student & -.0117 & $(0.15)$ & .1666 & $(2.26)$ & .0926 & $(1.27)$ & .2471 & $(3.34)$ \\
\hline Retired & -.0279 & $(0.46)$ & -.0188 & $(0.30)$ & -.0476 & $(0.76)$ & -.3204 & $(4.45)$ \\
\hline Housewife & .0351 & $(0.67)$ & .0161 & $(0.30)$ & -.0083 & $(0.15)$ & -.2221 & $(3.85$ \\
\hline Sick/disabled & .0126 & $(0.11)$ & .0039 & $(0.03)$ & -.0670 & $(0.58)$ & -.2511 & $(1.98)$ \\
\hline Other & -.1038 & $(0.98)$ & -.0849 & $(0.80)$ & -.2074 & $(1.92)$ & -.0663 & $(0.57)$ \\
\hline Male & .0439 & $(1.34)$ & .0597 & $(1.82)$ & .0866 & $(2.63)$ & .1181 & $(3.36)$ \\
\hline Age & -.0274 & $(18.87)$ & -.0216 & (14.94) & -.0188 & (12.94) & -.0251 & $(15.71)$ \\
\hline Years of schooling & .0413 & $(8.55)$ & .0462 & $(9.51)$ & .0553 & $(11.37)$ & .0820 & $(15.86)$ \\
\hline Years living in this town & -.0154 & $(14.61)$ & -.0180 & (16.83) & -.0159 & (14.84) & -.0093 & $(7.83)$ \\
\hline Lived abroad $<1$ year & .1901 & $(2.97)$ & .3038 & $(4.75)$ & .3901 & $(6.12)$ & .8478 & (13.07 \\
\hline Lived abroad $1-4$ years & .2949 & $(4.83)$ & .2959 & $(4.84)$ & .3651 & $(5.98)$ & .8976 & $(14.20)$ \\
\hline Lived abroad $>=5$ years & -.1291 & $(2.25)$ & -.0750 & $(1.30)$ & .1095 & $(1.89)$ & .9675 & $(16.17)$ \\
\hline Austria & -.1644 & $(2.21)$ & -.2450 & $(3.26)$ & -.2294 & $(3.05)$ & -.1312 & $(1.61)$ \\
\hline Canada & -.1262 & $(1.79)$ & .1171 & $(1.67)$ & -.1705 & $(2.39)$ & -.1419 & $(1.88)$ \\
\hline Ireland & -1.0202 & $(12.82)$ & -.8429 & $(10.44)$ & -.8392 & (10.34) & -.6972 & $(7.85)$ \\
\hline Italy & -.9312 & (12.04) & -.8849 & (11.03) & -.7617 & $(9.67)$ & -.7452 & $(8.31)$ \\
\hline Japan & --1.0843 & (14.95) & -.6910 & $(19.52)$ & -.5069 & (6.98) & -.6216 & $(7.55)$ \\
\hline Netherlands & -.0340 & $(0.53)$ & .2199 & $(3.45)$ & .1856 & $(2.92)$ & .3016 & $(4.48)$ \\
\hline New Zealand & -.2035 & $(2.06)$ & -.2280 & $(2.31)$ & -.1040 & $(1.06)$ & -.0721 & $(0.70)$ \\
\hline Norway & -.1320 & $(1.87)$ & -.0585 & $(0.83)$ & -.3813 & $(5.36)$ & -.2062 & $(2.66)$ \\
\hline
\end{tabular}




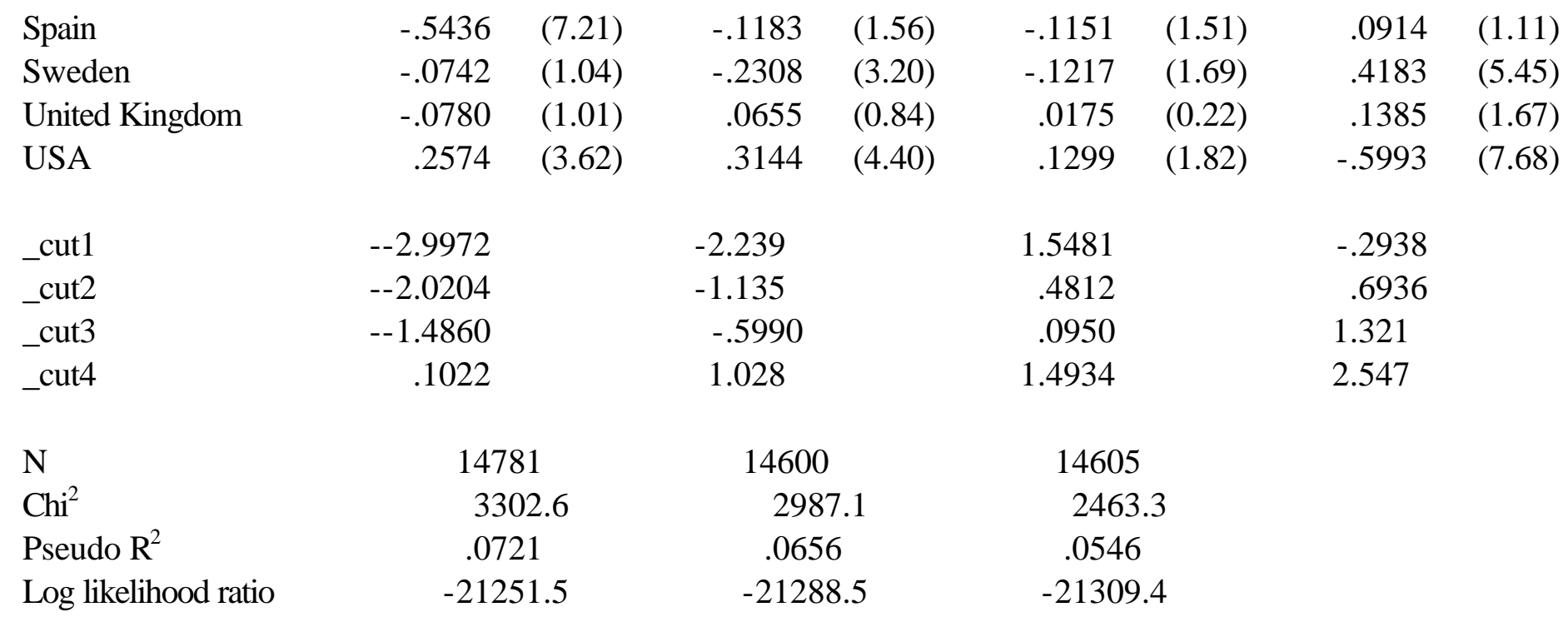

Notes: excluded categories are employees West \& East Germany, never lived abroad. t-statistics in parentheses. Method of estimation is ordered logit.

Source: International Social Survey Programme, 1995 
Table 14. Willingness to move flexibility index, 1995.

Neighborhood Town $\quad$ Region Rank sum Final rank $\begin{array}{r}\text { Self-empt. } \\ \text { Rate } 1996\end{array}$

\section{A) OECD Countries}

$\begin{array}{lr}\text { Austria } & 8 \\ \text { Canada } & \\ \text { Germany } & 12 \\ \text { Ireland } & 11 \\ \text { Italy } & 13 \\ \text { Japan } & \\ \text { Netherlands } & \\ \text { New Zealand } & 9 \\ \text { Norway } & \\ \text { Spain } & \\ \text { Sweden } & \\ \text { United Kingdom } & 5 \\ \text { USA } & \end{array}$

$\begin{array}{rr}8 & \\ 6 & \\ 2 & \\ 12 & \\ 11 & \\ 13 & \\ 3 & \\ 9 & \\ 7 & \\ 10 & \\ 4 & \\ 5 & \\ 1 & \end{array}$

B) All countries in sample

$\begin{array}{lrrrrr} & \text { Neighborhood } & \text { Town } & \text { Region } & \text { Rank Sum } & \text { Final rank } \\ \text { Austria } & 18 & 15 & 18 & 51 & 17 \\ \text { Canada } & 3 & 2 & 3 & 8 & 2 \\ \text { Czech Republic } & 16 & 13 & 16 & 45 & 15 \\ \text { Germany } & 5 & 3 & 5 & 8 & 2 \\ \text { Hungary } & 19 & 19 & 19 & 57 & 19 \\ \text { Ireland } & 17 & 17 & 17 & 51 & 17 \\ \text { Italy } & 10 & 8 & 10 & 28 & 10 \\ \text { Japan } & 15 & 18 & 15 & 48 & 16 \\ \text { Latvia } & 21 & 20 & 21 & 62 & 21 \\ \text { Netherlands } & 2 & 4 & 2 & 8 & 2 \\ \text { New Zealand } & 8 & 9 & 8 & 25 & 8 \\ \text { Norway } & 6 & 7 & 6 & 19 & 6 \\ \text { Philippines } & 14 & 16 & 14 & 44 & 14 \\ \text { Poland } & 12 & 12 & 12 & 36 & 12 \\ \text { Russia } & 20 & 21 & 20 & 61 & 20 \\ \text { Slovakia } & 11 & 10 & 11 & 32 & 11 \\ \text { Slovenia } & 13 & 14 & 13 & 40 & 13 \\ \text { Spain } & 7 & 11 & 7 & 25 & 8 \\ \text { Sweden } & 9 & 6 & 9 & 24 & 7 \\ \text { United Kingdom } & 4 & 5 & 4 & 13 & 5 \\ \text { USA } & 1 & 1 & 1 & 3 & 1\end{array}$


Source: International Social Survey Programme, 1995. 


\section{References}

Acs, Z and Evans, D. (1994), 'The determinants of variations in self-employment rates across countries and over time', working paper.

Alba-Ramirez, A. (1994), 'Self-employment in the midst of unemployment; the case of Spain and the United States’, Applied Economics, 26, pp. 189-204.

Arai, A.B. (1997). 'The road not taken: The transition from unemployment to self-employment in Canada, 1961-1994', Canadian Journal of Sociology, 22: (3) 365-382, Summer.

Aronson, R.L. (1991), Self-employment, ILR Press, Ithaca, New York.

Bendick, M., and Egan, M. L. (1987), 'Transfer payment diversion for small business development: British and French experience', Industrial and Labor Relations Review, 40, pp. 528-542.

Bernhardt, I. (1994), 'Comparative advantage in self-employment and paid work', Canadian Journal of Economics, May, pp. 273-289.

Birch, D.L. (1979), The job generation process, MIT program on neighbourhood and regional change, Cambridge, MA.

Black, J., De Meza, D. and Jeffreys, D. (1996), 'House prices, the supply of collateral, and the enterprise economy', Economic Journal, 106, January, pp. 60-75.

Blanchflower, D. G. and Freeman, R. B. (1994), 'Did the Thatcher reforms change British labour market performance?' in R. Barrell (Ed.) The UK labour market. Comparative aspects and institutional developments, Cambridge University Press.

Blanchflower, D. G. and,Freeman, R. B. (1997), 'The attitudinal legacy of communist labor relations', Industrial and Labor Relations Review, April, vol. 50 no. 3, pp. 438-459.

Blanchflower, D. G., Levine, P.B. and Zimmerman, D. (1998), 'Discrimination in the market for small business credit market', NBER Working Paper \#, Cambridge, MA.

Blanchflower, D. G. and Meyer, B. (1994), 'A longitudinal analysis of the young self-employed in Australia and the United States', Small Business Economics, 6, pp. 1-20.

Blanchflower, D. G. and Oswald, A. J. (1990), 'Self-employment and the enterprise culture', in British Social Attitudes: the 1990 Report, edited by Jowell, R., Witherspoon, S. and Jowell, R., Gower Press, Aldershot.

Blanchflower, D. G. and Oswald, A. J. (1994), The wage curve, MIT Press, Cambridge, 
Massachusetts.

Blanchflower, D. G. and Oswald, A. J. (1996), "An introduction to the wage curve', Journal of Economic Perspectives, Summer. pp. 153-67.

Blanchflower, D. G. and Oswald, A. J. (1998a), 'What makes an entrepreneur?', Journal of Labor Economics, January, 16(1) pp. 26-60, 1998.

Blanchflower, D. G. and Oswald, A. J. (1998c), 'Entrepreneurship and the youth labour market problem", a report to the OECD, Dartmouth College, Hanover, NH.

Blanchflower, D. G. and Oswald, A. J. (1999), 'Well-Being, Insecurity and the Decline of American Job Satisfaction', Working paper, Dartmouth College, Hanover, NH.

Blau, D. (1987), 'A time-series analysis of self-employment in the United States', Journal of Political Economy, 95, pp. 445-467.

Bogenhold, D. and Staber, U. (1991), 'The decline and rise of self-employment', Employment and Society, 5, pp. 223-239.

Borjas, George J. (1979), 'Job satisfaction, wages and unions', Journal of Human Resources, 14, pp. 21-40.

Borjas, G. J. and Bronars, S. (1989), 'Consumer discrimination and self-employment', Journal of Political Economy, 97, pp. 581-605.

Borland, J. and Home, R, (1994), 'Establishment-level employment in manufacturing industry: is small really beautiful?", Australian Bulletin of Labour, 20121: pp. 110-128, June.

Bregger J.E. (1996), 'Measuring self-employment in the United States', Monthly Labor Review, Jan/Feb. pp. 3-9.

Brown, C., Hamilton, J. and Medoff, J. (1990), Employers large and small, Cambridge: Harvard University Press.

Burrows R. and Ford J., (1998), 'Self-employment and home ownership after the enterprise culture', Work, Employment and Society, 12: (1), pp. 97-119 March.

Clark, A.E. (1966), 'Job satisfaction in Britain”, British Journal of Industrial Relations, 34(2), pp. 189217.

Clark, A. E. and Oswald, A. J. (1992), 'Satisfaction and comparison income', Journal of Public Economics, September, pp. 359-381. 
Clark, Andrew E. and Oswald, A. J. (1994), 'Unhappiness and unemployment', Economic Journal, 104, pp. 648-659..

Coate, S. and Tennyson, S. (1992), 'Labor market discrimination, imperfect information and selfemployment', Oxford Economic Papers, 44, pp. 272-288.

Cowling M, and Mitchell P. (1997), 'The evolution of UK self-employment: A study of government policy and the role of the macroeconomy', Manchester School of Economic and Social Studies, 65: (4) pp. 427-442, September.

Davis, S.J., Haltiwanger, J.C. and Schuh, S. (1996), Job creation and destruction, MIT Press, Cambridge, MA.

De Witt, G. and Van Winden, F. A. (1990), 'An empirical analysis of self-employment in the Netherlands', Economics Letters, 32, pp. 97-100.

Evans, D. and Leighton, L. (1989), 'Some empirical aspects of entrepreneurship', American Economic Review, 79, pp. 519-535.

Evans, D. and Jovanovic, B. (1989), 'An estimated model of entrepreneurial choice under liquidity constraints', Journal of Political Economy, 97, pp. 808-827.

Fairlie, R. W., (1999) 'The absence of the African-American owned business: an analysis of the dynamics of self-employment, Journal of Labor Economics, .

Fairlie, R. W., and B. D. Meyer (1996): "Ethnic and racial self-employment differences and possible explanations," Journal of Human Resources, 31(4), pp. 757-793.

Fairlie, Robert W., and Bruce D. Meyer (1998): "Does immigration hurt African-American selfemployment," in The Economic Implications of Immigration for African-Americans, eds., Daniel S. Hamermesh and Frank D. Bean, Sage Publications (forthcoming).

Foti A. and Vivarelli M. (1994), 'An econometric test of the self-employment model - the case of Italy', Small Business Economics, 6: (2), pp. 81-93 April.

Freeman, R. B. (1978), 'Job satisfaction as an economic variable', American Economic Review, 68, pp. 135-141.

Fuchs, V. (1982), 'Self-employment and labor force participation of older males', Journal of Human Resources, 17, Fall, pp. 339-357.

Gill, A. (1988), 'Choice of employment status and the wages of employees and the self-employed; 
some further evidence', Journal of Applied Econometrics, 3, pp. 229-234.

Hamermesh, Daniel S. (1977), 'Economic aspects of job satisfaction', in O. Ashenfelter and Wallace Oates (eds.), Essays in Labor Market Analysis, John Wiley, New York.

Holmes, T. J. and Schmitz, James A. (1990), 'A theory of entrepreneurship and its application to the study of business transfers', Journal of Political Economy, 89, pp. 265-294.

Holtz-Eakin, D., Joulfaian, D., and Rosen, H. S. (1994a), 'Entrepreneurial decisions and liquidity constraints', Journal of Political Economy, 102, pp. 53-75.

Holtz-Eakin, D., Joulfaian, D., and Rosen, H. S.(1994b), 'Sticking it out: entrepreneurial survival and liquidity constraints', Rand Journal of Economics, Summer, 25(2), pp. 334-347.

Huigen, R.D., Kleijweg, A.J.M. and van Leeuwen, G. (1991), 'The relationship between firm size and firm growth in Dutch manufacturing estimated on panel data", Netherlands Central Bureau of Statistics, The Hague.

Kanbur, S.M.Ravi (1982), 'Entrepreneurial risk taking, inequality, and public policy: an application of inequality decomposition analysis to the general equilibrium effects of progressive taxation', Journal of Political Economy, 90, pp. 1-21.

Kidd, M., (1993) 'Immigrant wage differentials and the role of self-employment in Australia', Australian Economic Papers; 32(60), June, pp. 92-115.

Kihlstrom, Richard.E. and Laffont, Jean Jacques (1979), 'A general equilibrium entrepreneurial theory of firm formation based on risk aversion', Journal of Political Economy, 87, pp. 719-848.

Kuhn, P.J. and Schuetze, H. J. (1998), 'The dynamics of self-employment in Canada', working paper, McMaster University.

Laferrere, A. McEntee P., (1995) 'Self-employment and intergenerational transfers of physical and human capital: an empirical analysis of French data', Economic and Social Review; 27(1), October, pp. 43-54.

Lazear, E. P., and R.L. Moore (1984): 'Incentives, Productivity, and Labor Contracts', Quarterly Journal of Economics, pp. 275-296.

Lentz B.F. and Laband, D.N. (1990), 'Entrepreneurial success and occupational inheritance among proprietors', Canadian Journal of Economics, 23, pp. 563-579.

Light, I. (1972): Ethnic Enterprise in America, Berkeley: University of California Press. 
Lindh T., and Ohlsson, H. (1996). "Self-employment and windfall gains: evidence from the Swedish lottery”, Economic Journal, 106: (439), pp.1515-1526, November.

Long, J.E., (1982), 'The income tax and self-employment', National Tax Journal, 35, March, pp. 31-42.

Meager, N. (1992), 'Does unemployment lead to self-employment?', Small Business Economics, 4 , pp. 87-103.

Meng, Ronald (1990), 'The relationship between unions and job satisfaction', Applied Economics, 22, pp. $1635-1648$

Moore, R.L. (1983): 'Employer discrimination: evidence from self-employed workers', Review of Economics and Statistics, 65, pp. 496-501.

Moulton, B.R. (1986). 'Random group effects and the precision of regression estimates', Journal of Econometrics, 32, pp. 385-397.

Moulton, B.R. (1987). 'Diagnostics for group effects in regression analysis', Journal of Business and Economic Statistics, 5, pp. 275-282.

Moulton, B.R. (1990). 'An illustration of a pitfall in estimating the effects of aggregate variables on micro units', Review of Economics and Statistics, 72, pp. 334-338.

OECD (1992), "Recent developments in self-employment', OECD Employment Outlook, July, pp. 155-194

Parker, S.C. (1997), 'The distribution of self-employment income in the United Kingdom, 1976-1991, Economic-Journal; 107(441), March, pp. 455-66.

Pickles, A.R. and O'Farrell, P.N. (1987), 'An analysis of entrepreneurial behavior from male work histories', Regional Studies, 21, pp. 425-444.

Picot, G., Baldwin, J. and Dupuy, R. (1994), 'Have small firms created a disproportionate number of new jobs in Canada? A reassessment of the facts', working paper, Statistics Canada, Ottawa.

Quinn, J.F. (1980), 'Labor force participation patterns of older self-employed workers', Social Security Bulletin, 43, pp. 17-28.

Reardon, E. (1998), ‘Are the self-employed misfits or superstars?’, Rand Corporation, working paper.

Rees, H. and Shah, A. (1986), 'An empirical analysis of self-employment in he UK', Journal of Applied Econometrics, 1, pp. 95-108. 
Robson, M.T. (1998a), 'The rise in self-employment amongst UK males', Small Business Economics, 10: (3), pp.199-212.

Robson, M.T. (1998b), 'Self-employment in the UK regions', Applied Economics, 30: (3) pp. 313322.

Rogers, W. H. (1993), 'Regression standard errors in clustered samples”, Stata Technical Bulletin 13; 19-23, reprinted in Stata Technical Bulletin Reprints vol 3, pp. 88-94.

Schuetze, H.J. (1998), 'Taxes, economic conditions and recent trends in male self-employment; a Canada-US comparison', working paper, McMaster University, Hamilton, Ontario, Canada.

Sowell, T. (1981), Markets and Minorities, New York: Basic Books.

Taylor, M.P. (1996), 'Earnings, independence or unemployment; why become self-employed?', Oxford Bulletin of Economics and Statistics, 58(2), pp. 253-265.

Wagner, J. (1995), 'Firm size and job creation in Germany', Small Business Economics; 7(6), December, pp. 469-74.

Wolpin, K. (1977), 'Education and Screening', American Economic Review, pp. 949-958. 